Al-Vlum

Volume 15 Number 2 December 2015

Page 371 - 386

\title{
Managing Islamic Education to Overcome Juvenile Delinquency
}

\author{
M. Rapi \\ STAIN Watampone \\ rapianci@yahoo.co.id
}

\begin{abstract}
Reconstructing patterns of Islamic education to be basic values of religion provides the scope of Islamic education development. Education is an effort to preserve, transfer and transform cultural good values in all its aspects to the younger generation. Patterns of Islamic education in tackling juvenile delinquency including efforts to improve Muslim education strategies concerning the issue of how the implementation of the educational goals of the educational process by looking at the situation and condition, and also how to keep the process there are no disturbances, internally and externally, regarding institutional or social environments. The application of preventive methods (prevention), curative (treatment) and rehabilitative (quarantine) are pivotal for an educator or school organizers, to coach young people in schools can be focused well; therefore, at least it is to reduce misbehavior frequency among adolescents.
\end{abstract}

Rekonstruksi pola pendidikan Islam merupakan suatu keharusan dalam menempatkan nilai-nilai dasar agama yang menyediakan lingkup pengembangan pendidikan Islam. Pendidikan adalah upaya untuk melestarikan, mentransfer dan mengubah nilai-nilai budaya dalam segala aspeknya yang baik untuk generasi muda. Pola pendidikan Islam dalam menanggulangi kenakalan remaja termasuk upaya untuk meningkatkan strategi pendidikan Islam mengenai masalah bagaimana pelaksanaan tujuan pendidikan dari proses pendidikan dengan melihat situasi dan kondisi, serta bagaimana untuk menjaga proses tersebut supaya berjalan tanpa hambatan, internal dan eksternal, dalam lingkungan kelembagaan atau sosial. Penerapan metode preventif (pencegahan), kuratif (pengobatan) dan rehabilitatif (karantina) sangat diperlukan untuk seorang pendidik atau sekolah penyelenggara untuk pembinaan generasi muda di sekolah-sekolah dapat difokuskan baik sehingga setidaknya mengurangi frekuensi perilaku negatif yang terjadi pada remaja.

Keywords : Juvenile Delinquency; Managing Islamic Education 


\section{A. Introduction}

An education is an institution for shaping, inheriting, and developing the culture of human beings. The purpose of Islamic education is not just the secular affairs but also relates to the combination between the spiritual and physical affairs. By other terms, the Islamic education prepares someone to behave appropriately (ihsan) to face the world and the life hereafter.

Accordingly, Islamic education does not only prepare students to play a role as individuals and as members of society, but also the more important is that as the Caliph of Allah.

Therefore, someone is cohesive to the demands of his life due to the spirit. The education, then, is the primary means required for the development of human life in a equivalent dimension to the level of creativity power, sense power, and intention power of the community and its members. ${ }^{1}$

The role of education as an element of the social dynamics has a contribution to the inequality reduction in society. The function and the role of Islamic education, in the effort to overcome the juvenile delinquency, requires a concept that is always relevant to the development of adolescents, especially present youths, who have come into contact with modern cultures. The concept of education that already exists, or that we all know, it does not mean the concept is outdated or no longer valid, but the education concept should be able to keep up with the times by looking at social conditions.

In relation to juvenile delinquency that is the crowded cases in big cities, it is necessary to do strategy back to the concept of Islamic education. Considering that the today's juvenile delinquency is no longer requires the concept of education which only refers to the Qur'an and the hadith, but it requires new patterns of methods, curriculum, teachers, approaches, and materials in education.

The intended concept strategy of Islamic education is the necessity of rethinking the concept of Islamic education that already exists in the schools, both public and religion. The concept strategy of education may includes approaches, guidance to youth, appropriate media for adolescents,

${ }^{1}$ H. Z. Jusuf (ed.), Pendidikan Efektif Agama Islam (Jakarta: IKIP, 1988), p. 223 
and methodological transformation of Islamic education values, using the general curriculum combined with religious knowledge as well as preventive measures for the youths from the action against the law, or other asocial acts.

Islamic education strategies are needed by the school, especially schools that are oriented to public school, or the ones who thought that the religious education guidance for students only the responsibility of the religious teachers themselves. Based on the above description, the writer feels compelled to examine and investigate the problem by research entitled "Islamic Education Management in Overcoming Juvenile Delinquency"

\section{B. Theories}

\section{The Concept of Islamic Education Strategy}

In general, the strategy can be defined as an outline of policy to act in order to achieve specific targets. In line with learning, a strategy can be defined as common patterns of activities of teachers, students in the realization of teaching and learning activities to achieve the objectives that have been outlined. ${ }^{2}$

In the implementation of Islamic education process, particularly in terms of teaching and learning strategy development, it should also be considered the principal task of Islamic education in anticipation of the science and technology development. Islamic education that has main duty to examine, to analyze and to develop ideas, information and facts about education that have same congruent with the values of Islam should be able to summon program planning and operational activities of education, especially with regard to the development and utilization of science and technology of modern as well as the way to anticipate negative developments that occurred in the field of social and religious life of the society. ${ }^{3}$

According to HM Arifin, Islamic education strategy in facing the challenges of modernization because of science and technology covers: ${ }^{4}$

${ }^{2}$ See Syaiful Bahri Djamarah dan Aswin Zain, Strategi Belajar Mengajar (Cet. I; Jakarta: Rineka Cipta, 1996), p. 5-6.

${ }^{3}$ See H.M. Arifin, Kapita Selekta Pendidikan Agama Islam (Cet. IV; Jakarta: Bumi Aksra, 1998), p. 46.

${ }^{4}$ See ibid. 
1. Motivating the creativity of the students towards the development of science and technology itself where the values of Islam become a source of reference.

2. Educating the skills of the students to utilize science and technology products for the welfare of mankind in general and Muslims in particular.

3. Creating a strong tangle between religion and science and technology as well as a close relationship with the scientists who hold the authority of science and technology in their respective fields.

4. Instilling the attitude and extensive insight of the future life of mankind through the ability to interpret the religious teachings based on the pure sources and those are contextual to the future of human life.

As the agent of social change, Islamic education is required to play a role in a dynamic and proactive. Among the various problems of large entanglement, it is also confronted to the challenges and prospects for the future. Whether or not Islamic education gets out from the entanglement of these problems and participates actively in the crowded of changes movements in intellectual and socio-cultural. ${ }^{5}$ Obviously, this problem is the biggest challenge being faced by Muslims, especially Islamic education as a measure of the change and progress of Muslims.

In essence, education is the process related to the effort to the potential development in a person which includes three aspects of life namely the way of life, the attitude of life, and the skill of life. These three aspects in the most used term are cognitive, affective and psychomotor. All three are unified totality inherent in a person. ${ }^{6}$

In general, the educational activities including Islamic education can be divided into three sections, namely education by themselves, education by the environmental education, and education by others against a particular person. Similarly, the places of education are also consist of three places namely in the home, in the community and in the school. The

${ }^{5}$ See Abd. Wahid dalam Ismail S.M., Nurul Huda, Abdul Khalik (ed.), Paradigma Pendidikan Agama Islam (Cet. I; Yogyakarta: Pustaka Pelajar, 2001), p. 275.

${ }^{6}$ See ibid., p. 214-215. 
ffforts to develop the three aspects above (cognitive, afektif, and psychomotor) can be implemented in all the educational levels. ${ }^{7}$

In order to anticipate the various problems faced by the Muslims, the teaching of religious education in schools must provide fruitful contribution. It must be realized that there are many criticisms of the implementation of the ongoing religious education in schools nowadays. Mochtar Buchori, for example, assesses the failure of religious education due to educational practice that only concerns with cognitive aspects of religious values growing awareness and ignores the development of the other aspects (afektif and psychomotor) that are also the determinant aspects to strengthen the contribution of religious education. As a result, there is a gap between knowledge and experience in the religious values practice. In the religious education context, it is changed into religious teachings so that it is not able to form Islamic personalities. The same thing is also stated by Harun Nasution that religious education is much influenced by Western trend that emphasizes teaching moral education more than educating it whereas the essence of of religious education is educationg moral education. ${ }^{8}$

The teachers in the school ideally should not teach the students in various sciences and fill their brains and minds without regard to their mental and moral development, but they have full responsibility in moral coaching and development of students.

\section{Juvenile Delinquency Definition}

Juvenile delinquency is a behavior or actions that are asocial, there may be violations of social norms and prevailed religion in society. According to M.Gold and J.Petrono, juvenile delinquency is the act by someone who is not an adult who intentionally violate the law and it is known by him that if the act is known by the officers of the law he could be punished. ${ }^{9}$

Considering the above definitions, of course, every one agrees in defining juvenile delinquency as abnormalities in behavior and actions of teenagers who are asocial and constitutes a violation of social norms of law and norms of the religion developing in the society.

\section{${ }^{7}$ See ibid.}

${ }^{8}$ See Muhaimin, Paradigma Pendidikan Agama Islam (Cet. I; Bandung: PT. Remaja Rosdakarya, 2001), p. 88.

${ }^{9}$ See Sarlito Wirawan Sarwono, op. cit., p. 136. 
Today the definition of juvenile delinquency is developing in broader sense includes judicial, sociological, moral and decency. ${ }^{10}$ The popularity of the term "juvenile delinquency" can be identified when it is never missed in the environment, both in small cities and in big cities. Recently, the teenagers instead of achievement that they dedicate to the nation, the mischief which peaked like a fire blazing in the sky the show.

\section{The Forms of Juvenile Delinquency}

According Zakiah daradjat, juvenile delinquency can be categorized into three forms, namely: 1) juvenile delinquency light, for example, uncompromising, unwilling to be obedient to their parents and teachers, ditching, being lazy to learn, fighting, conveying words that are not polite, etc., 2) juvenile delinquency by disturbing the peace and security of other people, for example; stealing, slandering, robbering, molesting, destroying property of others, murder, speeding, etc., and 3) sexual juvenile delinquency, for example, heterosexual, homosexual, and lesbian. ${ }^{11}$

Zakiah daradjat seems to divide the three forms of juvenile delinquency with a view of the psychology and sociology that describe the teenegers in the asocial actions are motivated and influenced by their family background and environment.

If it is associated with the rule of law, juvenile delinquency, according to Ny. Singgih D. Gunarsah, can be divided into two major groups, namely: ${ }^{12}$

1. Delinquency who is amoral and asocial but it not regulated by law, so it can not be classified as a violation of law.

2. Delinquency who is unlawful in accordance with the applicable law. It can be classified as unlawful actions if these are committed by an adult.

While the delinquency that is considered unlawful resolved through legal and can often referred to as a crime. This crime can be classified according to the severity of the felony offense, for example; gambling and all forms of gambling using money, theft, pickpocketing, robbery, mugging, embezzlement, fraud, breach of deontology (selling pornographic images and porn), forgery, murder, attempted murder,

\footnotetext{
${ }^{10}$ See Sudarsono, Etika Islam tentang Kenakalan Remaja (Cet. II; Jakarta: Rineka Cipta, 1991), p. 7.

${ }^{11}$ See Zakiah Daradjat, op. cit., p. 10-11.

${ }^{12}$ See Ny. Singgih D. Gunarsa, op. cit., p. 30-31.
} 
abortion, drug abuse, involved in narcotics (drugs) and other addictive substances. ${ }^{13}$

From the view of Islam, the juvenile delinquency is not distinguished between ordinary delinquency (which are not entangled with the law) and which can be categorized as a violation of the law or criminal. Considering that the initial offense which initially only ordinary delinquence can be developed into a crime against the law. In this case, Islam established itself as a problem solver (in anticipation of juvenile delinquency that arises in the society).

\section{Research Result and Discussion}

\section{The Strategy of Islamic Education}

In the implementation of Islamic education in schools, there are six strategies of Islamic education in schools that should be done by teachers, namely: ${ }^{14}$

1. Excitement and willingness to learn

An experienced teacher does not encourage his students to learn something beyond his ability. He also does not pump knowledge to their brain knowledge that is not in accordance with their maturity or their prior knowledge. It can be said that in the process of teaching, teachers should pay attention to the students, their growth as well as individual differences existing among them.

2. Arousing the interest of the students

The teachers must maintain the class rule and arouse the the students' interst to accept the lesson. They also must direct them to desiredly good behavior voluntarily or on their own work and move. The strategies to implement it are arousing the students' interest by accomodating their needs and keeping their talent and directing it to the right.

3. Establishing the good attitude and talent

The are many kinds of aktivities to be undertaken by the students in learning where the teacher can try to generate interest and needs as well as establish their various talents and attitudes that are part of their personality. All the efforts will excite them and affect their future and their life in general.

\footnotetext{
${ }^{13}$ See Sudarsono, Kenakalan Remaja (Cet. II; Jakarta: Rineka Cipta, 1995), p. 32-64.

${ }^{14}$ See ibid., p. 22-23.
} 


\section{Setting the teaching and learning process}

Setting the learning experiences as well as activities that are in relationship with it is a major factor in the success of the learning process, because it will facilitate the students to gain the experience and use it. The setting is conducted by connecting the elements of the lesson with students' activities where the theacher make it as a unified whole that revolve around the issues that concern them. Thus, learning becomes meaningful.

5. The transfer of the learning effect and its implementation in real life

To success the learning process and make it useful in life outside of school, the teachers must understand the basic cases that allow the transfer of learning effect into life outside of school as well as its implementation.

6. Human relationships in the learning process

The learning process can run smoothly or halt depends on social relationship in the classroom between teachers and the students as well as among the fellow students that is suitable to the social situation that stands out in the classroom. Therefore, the teachers have just understood various social relationships in the teaching and learning proces.

Hence, education must be a primary guidance in the effort of the students' development optimally, both as a individual person and as a member of society. This ideal aspect must be embedded in the basic attitude of a teacher as an educator and it is manifested in the teachers' approach toward students in accordance with their development stage and implemented either individually or in groups classically.

The education strategy is essentially a science or art to utilize all the factors or forces to secure the objectives of education to be achieved through planning and direction in the operation in accordance with the circumstances existing field, including the calculation of the constraints either physically or in the form of non-physical (such as mental, spiritual, and moral, kind of subject, object, and the environment).

Considering several descriptions of the above educational strategies, especially those leading to the formation of an Islamic personality, we can understand that the education strategy can also be interpreted as a policy and a common method in the implementation of education.

\section{The Strategy to Overcome Juvenile Delinquency}

Teenagers are very large potentials of the nation and, of course, have a strategic and decisive role, both in the present and in the future. The potential and the major role would only be empowered verbal language if 
those do not fit the existing order. It may be great a potential will be wasted, both to themselves and the interests of the nation as a whole.

Teenagers or youths are all while experiencing the challenges internally and externally. The challenges are always to be faced even though those may sometimes require some sort of resistance against themselves. A situation which seems to proceed naturally, but in fact they are in a difficult social environment configuration to decide its tip lines.

The external challenges are in the form of economic globalization and the information technology demanding competition and quality of human resources that is high so as to make the challenge as an opportunity. In addition to the challenges that are economically productive, another challenge is the struggle with foreign cultures (global) that can eliminate identity and culture of its own nation.

To provide appropriate solution to the faced problems and challenges by teenagers, it should be reviewed in advance of the subject, then the form and nature of the actions. Therefore, the teenagers should be considered: ${ }^{15}$

1. As individuals who are still in transition to be adult.

2. As individuals who need and deserve help in their development.

3. As individuals that suffer or at least experience developmental abnormalities.

4. As individuals that experience difficulties and failures in the process of education and training.

5. As individuals who are victims rather of the social change, especially due to the lack of proper development technology use

The characters that are inherent to the tenagers generally are the following characteristics: ${ }^{16}$

1. They have a complete and powerful physical energy

2. They have a lack experience

3. They a strong identification of imagination

4. They are experiencing reconstruction period

5. They like to give a reaction to challenges

6. They tend to react to a situation

7. They tend to agains authority

8. They have great potetials

${ }^{15}$ See Sahilun A. Nasir, Peranan Pendidikan Agama Terhadap Pemecahan Problema Remaja (Cet. I; Jakarta: Kalam Mulia, 1999), p. 89.

${ }^{16}$ See ibid., p. 90. 
9. They are easily frustrated

10. They have strong wish to have attention, appreciation, and role in society.

11. They have varous forms of motivation.

To avoid swelling problems faced by the teenagers, it is necessary to provide targeted prevention.

To face juvenile delinquency also, it is needed for actions, namely: ${ }^{17}$

1. Preventive actions namely all actions aimed at preventing the rising of naughtiness.

2. Repressive actions namely all actions to suppress and restrain juvenile delinquency as possible or impede the rising of more severe delinquency events.

3. Curative actions or rehabilitation namely all actions to improve the result of mischievous deeds, especially individuals who have committed such acts

In addition, the role of religion is very important because religion provides guidance and rules that are defined and adhered to voluntarily on impulsing within themselves, not imposed from outside. ${ }^{18}$

After finding out that the problem of juvenile delinquency is a problem that is very complex and it is caused by various factors, then the countermeasures requires various efforts, among others, the most important is the effort of prevention, so that the mischief can be contained and does not transmitted to the ones who are still good. Of course, repression and rehabilitation efforts also need to be considered, so a naughty teenager can be repaired and returned to live as a good member of society. ${ }^{19}$

To determine the extent of the efforts of preventive, repressive, curative and rehabilitation needs to be done, as well as scope-scope in terms of prevention of juvenile delinquency, the following will discuss these efforts and alternative solutions.

1. Preventive Actions

a. Education Field

In accordance with the teachings of Islam, an opinion of psychotherapy expert states that each experience that a child experiences

${ }^{17}$ See Ny. Singgih D. Gunarsa dan Singgih D. Gunarsa, Psikologi Remaja (Jakarta: Gunung Mulia, 1991), p. 161.

${ }^{18}$ See Zakiah Daradjat, "Membina Nilai-nilai Moral", op. cit., p. 84.

${ }^{19}$ See ibid. 
in his life, whether through sight, hearing, received treatment, etc. come to be a part of the shaping personality. Therefore, religious education in the family education that is inspired by religious education especially for children who are still in the phase of passive education when growth is still lacking of intelligence must be assessed. Parents should set an example in his life, such as regular worship and pray to the Lord's, in addition to take children to imitate the attitude. While in the association and the treatment of children, the parents must show compassion, honesty, truth and justice in all matters. ${ }^{20}$

Among the efforts of education development in the family are as follows: ${ }^{21}$

1) Avoiding family cracks (broken home or a broken family).

2) Instilling religious education in accordance with the level of development such as faith, morals and worship.

3) Maintenaning bonds of affection that is fairly and equitably among family members.

4) Intensive monitoring to the symptoms of activity undertaken by children to suppress the possibility of negative behavior.

5) Providing a useful activity as well as responsibility.

6) The division of roles and responsibilities among family members School as a second environment after family plays a very important, especially in the development of mental attitude, knowledge and skills of the child. The target of this development is the teenagers' growth to be dynamic and critical in thinking and acting. This situation will reduce the frequency of irregularities occurrence. ${ }^{22}$

In this context, the school is an educational event that is second after family environment for teenagers. In the big cities in Indonesia, adolescence is a period in school, especially in the early stages. In this period generally teenagers attend junior high school or higher level. ${ }^{23}$

In realizing a healthy school environment, the effort can be started from settting rules about uniforms with the intention that the students appear in harmonious life. It minimizes luxury protrusion that may occur between them as well as educates them to live simply in the school

${ }^{20}$ See ibid., p. 87.

${ }^{21}$ See Sahilun A. Nasir, op. cit., p. 90-94.

${ }^{22}$ See ibid., h. 92.

${ }^{23}$ See Sudarsono, Kenakalan Remaja (Cet. III; Jakarta: Rineka Cipta, 1995), p. 129. 
environment in particular. In certain times, rule operation is held in the school environment continuously. These efforts are conductes as much as possible to eliminate the sources of juvenile delinquency. If it is considered crucial, contacts with the families of students at home may be conducted so that parents or guardians participate in inspiring them to fulfill the obligations in school and motivate them to be able to improve the quality or learning achievement in all fields. ${ }^{24}$

Preventive efforts that are conducted in schools include:

1) Intensifying religious education lessons.

2) The application of the methodology of effective teaching and learning that can interest the motivation and attention of children so that children learn to be more active.

3) In the implementation of the curriculum, the adequately balance of cognitive, affective, psychomotor must be considered.

4) Reforming and fulfilling educational facilities.

5) Increasing supervision and discipline of the school rules.

6) Holding identification and guidance regarding talents, interests, capabilities and its distribution.

7) Training and getting children to cooperate and to organize with the guidance of teachers through the school organization.

Equally important to maintain the stability of teenagers' life are organizations or youth associations, both formal (scout movement, karang taruna), or informal (youth group of students) and so on. But it is important to be considered if the organization or the group itself is not stable, a lot of turbulences may exist or it consists of friends who are also full of turbulances (eg aisle). As the result, the teenagers who join the group as it will only increase deviant behavior. ${ }^{25}$

Public is the third place of education after family and school. The guidance in public education is intended to fill free time with useful activities. This can be done by improving the education of scouting, religious mental counseling, skills training, coaching sports, karang taruna, mosques teenagers, and other efforts. ${ }^{26}$

${ }^{24}$ See ibid., p. 131.

${ }^{25}$ See Sarlito Wirawan Sarwono, Psikologi (Cet. V; Jakarta: Raja Grafindo Persada, 2000), p. 219-220.

${ }^{26}$ See Sahilun A. Nasir, op. cit., p. 94. 
The efforts that support the development need means for the teenagers to conduct their creativity. For the sake, adequate facilities, such as youth centers, gyms, mental coaching group and others are needed. ${ }^{27}$

\section{Conclusion}

Reconstructing the patterns and basic insights of Islamic education means a necessity to put basic religious values that give scope the development of Islamic educational process in order to achieve the goal. In a society that is dynamic, insightful educational role that determines the existence and development of society. Therefore, education is an attempt to preserve, to transfer, andt to transform the values of culture in all its aspects and kind to the teenagers.

Adolescent and its problems absorb a particular concern in the community especially about the issue of juvenile delinquency that is more intense today. Juvenile delinquency becomes a challenge that must be faced and overcomeby parents, educators in formal environments, even the government that is quite giddy to think about teenagers and their mischief.

The patterns of Islamic education in overcoming juvenile delinquency including efforts to improve Islamic education strategies concerning the issue of how the implementation of the education process on educational goals by looking at the situation and the existing conditions and also how the process can ban run without obstacles and interference both internal and externally regarding institutional or social environment. The application of the methods of prevention, the curative, and rehabilitative is necessary for educators or organizers of school so that coaching teenagers in schools can be directed well that at least to reduce the frequency of juvenile delinquency that occurs in adolescents

${ }^{27}$ See Sahilun A. Nasir, op. cit., p. 97. 


\section{REFERENCE}

Al-Qur'an al-Karim.

Arifin, H.M. Ilmu Pendidikan islam, Suatu Tinjauan Teoritis dan Praktis Berdasarkan Pendekatan Interdisipliner. Cet. IV; Jakarta: Bumi Aksara, 1996.

Arifin, H.M. Kapita Selekta Pendidikan Islam dan Umum. Cet. III; Jakarta: Bum Aksara, 1995.

Arsyad, Azhar. Media Pengajaran. Cet. II; Jakarta: PT. Raja Grafindo Persada, 2000.

Cangara, Hafied. Pengantar Ilmu Komunikasi. Cet. II; Jakarta: PT. Raja Grafindo Persada, 2000.

Danim, Sudarmin. Media Komunikasi Pendidikan. Cet. I; Jakarta: Bumi Aksara, 1994.

Daradjat, Zakiah, dkk. Ilmu Pendidikan Islam. Cet. II; Jakarta: Bumi Aksara, 1996.

Daradjat, Zakiah, dkk. Metodologi Pengajaran Agama Islam. Cet. I; Jakarta: Bumi Aksara, 1996.

Daradjat, Zakiah, dkk. Ilmu Jiwa Agama. Cet. III; Jakarta: Bulan Bintang, 1973.

Daradjat, Zakiah, dkk. Kepribadian Guru. Cert. II; Jakarta: Bulan Bintang, 1982.

Daradjat, Zakiah, dan Zaini Muchtarom (ed.). Islam Untuk Disiplin Ilmu Pendidikan. Cet. I; Jakarta: Bulan Bintang, 1987.

Departemen Agama RI. Al-Qur'an dan Terjemahnya. Cemarang: CV. Toha Putra, 1989.

Djamarah, Syaiful Bahri dan Aswin Zain. Strategi Belajar Mengajar. Cet. I; Jakarta: Rineka Cipta, 1996. 
Getteng, Abd. Rahman. Pendidikan Islam dalam Pembangunan. Cet. I; Ujung Pandang: Yayasan al-Ahkam, 1997.

Gunarsa, Ny. Y. Singgig D. dan Singgih D. Gunarsa. Psikologi Remaja. Jakarta: Gunung Mulia, 1991.

Hajjaj, Abu al-Hasan Muslim bin. Shahih Muslim. Jakarta: Maktab Dahlan, t.th.

Jusuf, H.Z. (ed.). Pendidikan Efektif Agama Islam. Jakarta: IKIP, 1988.

Langgulung, Hasan. Manusia dan Pendidikan. Cet. III; Jakarta: al-Husna Zikra, 1995.

Mappanganro. Implementasi Pendidikan Islam di Sekolah. Ujung Pandang: Yayasan al-Ahkam, 1996.

Marimba, Ahmad D. Pengantar Filsafat Pendidikan Islam. Cet. VII; Bandung: PT. Al-Ma'arif, 1989.

Muhaimin. Paradigma Pendidikan Islam. Cet. I; Bandung: PT. Remaja Rosdakarya, 2001.

Nahlawi, Abd. Al-Rahman. Usul al-Tarbiyah al-Islamiyah wa 'Asalibiha, diterjemahkan oleh Shihabuddin dengan judul "Pendidikan islam di Rumah, Sekolah dan Masyarakat". Cet. II; Jakarta: Gema Insani Press, 1996.

Nasir, Sahilun A. Peranan Pendidikan Agama Terhadap Pemecahan Problema Rem,aja. Cet. I; Jakarta: Kalam Mulia, 1999.

Poerwadarminta, W.J.S. Kamus Umum Bahasa Indonesia. Cet. V; Jakarta: PN. Balai Pustaka, 1996.

Ramayulis. Ilmu Pendidikan Islam. Cet. II; Jakarta: Kalam Mulia, 1998.

Sarwono, Sarlito Wirawan. Psikologi Remaja. Cet. V; Jakarta: Raja Grafindo Persada, 2000.

Sudarsono. Kenakalan Remaja. Cet. III; Jakarta: Rineka Cipta, 1995. 
Supriatna. Strategi Pembangunan dan Kemiskinan. Jakarta: Rineka Cipta, 2000.

Tafsir, Ahmad. Ilmu Pendidikan dalam perspektif Islam. Cet. III; Bandung: PT. Remaja Rosdakarya, 2000.

Ulwan, Abdullah Nashih. Tarbiyat al- 'Aulad fi islam, diterjermahkan oleh Jamaluddin Miri dengan judul "Pendidikan Anak dalam Islam”. Cet. I; Jakarta: Pustaka Amani, 1995.

Walgito, Bimo. Bimbingan dan penyuluhan di Sekolah. Cet. IV; Yogyakarta: Andi Offset, 1993. 